\title{
WEED INTERFERENCE IN COTTON PLANTS GROWN WITH REDUCED SPACING IN THE SECOND HARVEST SEASON ${ }^{1}$
}

\author{
MICHEL ALEX RAIMONDI ${ }^{2 *}$, RUBEM SILVÉRIO DE OLIVEIRA JUNIOR ${ }^{3}$, JAMIL CONSTANTIN $^{3}$, LUIZ \\ HENRIQUE MORAIS FRANCHINI ${ }^{3}$, ÉDER BLAINSKI ${ }^{4}$, RICARDO TRAVASSO RAIMONDI ${ }^{3}$
}

\begin{abstract}
Changes in row spacing may result in changes in crop and weed behavior and crop-weed competition. A study was performed to determine the periods of weed presence and weed control in cotton sown with $0.76 \mathrm{~m}$ spacing between planting rows. Cotton cultivar FM 993 was sown on 01/08/2010 with the aim of reaching a density of 190,000 seeds $\mathrm{ha}^{-1}$. Treatments with either weed presence or weed control during the first $0,5,10,15,22,29,36,43,50,57,64,71$, and 190 days of cultivation were established to determine the period prior to weed interference (PPI), total period of interference prevention (TPIP) and critical period of weed control (CPWC). The weed species with high relative importance were Amaranthus retroflexus, Bidens pilosa, Eleusine indica, Digitaria horizontalis, Alternanthera tenella, and Commelina benghalensis. Considering a maximum yield loss of 5\%, the PPI was established 11 days after cotton emergence (DAE), the TPWC at 46 DAE, and the CPWC between 11 and 46 DAE, for a total duration of 35 days. Considering a maximum acceptable yield loss equal to the standard deviation for the weed-free treatment, the PPI was established at 6 DAE, the TPWC at 55 DAE, and the CPWC between 6 and 55 DAE for a total duration of 49 days.
\end{abstract}

Keywords: Sowing season. Gossypium hirsutum L.. Interference period. Weeds.

\section{MATOINTERFERÊNCIA NO ALGODOEIRO EM FUNCÃO DE ESPAÇAMENTO REDUZIDO NA "SEGUNDA SAFRA"}

RESUMO - Alterações no espaçamento de semeadura podem gerar modificações no comportamento da cultura, das plantas daninhas e nas relações de competição entre ambas. Um experimento foi desenvolvido para determinar os períodos de convivência e controle das plantas daninhas no algodoeiro, semeado em espaçamento de $0,76 \mathrm{~m}$ entre linhas. A semeadura do cultivar FM 993 foi realizada no dia 08/01/2010 buscando-se atingir uma densidade de 190 mil sementes ha ${ }^{-1}$. Para determinar os períodos de convivência, período anterior a interferência (PAI), período total de prevenção da interferência (PTPI) e período crítico de prevenção à interferência (PCPI), foram analisados os períodos de $0 ; 5 ; 10 ; 15 ; 22 ; 29 ; 36 ; 43 ; 50 ; 57 ; 64 ; 71$ e 190 dias de convivência ou de controle inicial das plantas daninhas. As plantas daninhas de maior importância relativa foram Amaranthus retroflexus, Bidens pilosa, Eleusine indica, Digitaria horizontalis, Alternanthera tenella e Commelina benghalensis. Admitindo-se a perda máxima de 5\% em relação a produtividade, o PAI foi de 11 dias após a emergência após a emergência (DAE), o PTPI foi de 46 DAE e o PCPI de 35 dias, entre 11 e 46 DAE. A tolerância equivalente ao desvio padrão da média do tratamento no limpo resultou no PAI de 6 DAE, PTPI de 55 DAE e PCPI com duração de 49 dias, entre 6 e 55 DAE.

Palavras-chave: Época de semeadura. Gossypium hirsutum L.. Período de interferência. Plantas daninhas.

\footnotetext{
*Corresponding author

${ }^{1}$ Received for publication in $06 / 06 / 2014$; accepted in 07/04/2016.

Paper extracted from the doctoral thesis of the first author.

${ }^{2}$ Agro MR, Francisco Alves, PR, Brazil; michelraimondi@hotmail.com.

${ }^{3}$ Center for Advanced Studies in Weed Research/Agronomy Departament, Universidade Estadual de Maringá, Maringá, PR, Brazil; rsojunior@gmail.com, constantin@teracom.com.br, lhfranchini@gmail.com, ricardo.tr.agro@gmail.com.

${ }^{4}$ Terra Paraná Agricultural Research and Training, Assis Chateaubriand, PR, Brazil; ederblainski@gmail.com.
} 


\section{INTRODUCTION}

Over the last few years, many Brazilian cotton farmers have opted to sow cotton during the second harvest season, usually with reduced spacing between planting rows. When cotton is sown in late December or early January, the spacing between planting rows can be reduced and the plant density increased. This set-up is primarily due to the lower accumulated rainfall until the end of the crop cycle and the lower rainfall at the time of opening of the first fruits. The most often used spacing for second harvest sowing is $0.76 \mathrm{~m}$ between planting rows, which increases the plant density up to approximately 150,000 plants $\mathrm{ha}^{-1}$. Later sowing with decreased spacing may increase the fiber yield per unit area and especially result in higher precocity of the crop production cycle. Its advantages are the reduced application of plant protection products with consequently lower production costs and higher profits and the possibility of performing two harvests per year (FAIRCLOTH et al., 2004).

The optimization of spacing and time of sowing have become a major focus of the discussions regarding the cotton production chain. Different cotton cultivation systems with different sowing times, plant spacing, and densities present differences in crop physiology, climate, pest control, plant diseases, and especially weed management and periods of weed competition with cotton. The environment affects all plant developmental stages and may affect plant growth and development and the quantity and quality of the final product. Therefore, changing the crop cultivation system affects crop production management (STEPHENSON et al., 2011; SILVA et al., 2006).

The combination of the production environment of the Cerrado regions and new cultivation systems demand increasingly higher knowledge about crop management, especially regarding harvesting, fiber processing, pest and disease control, and weed management to achieve a high yield and obtain a final product with the highest possible quality.

The present study was performed in the Brazilian Cerrado with the aim of identifying the periods of weed interference on cotton sown during the second harvest season with $0.76 \mathrm{~m}$ spacing between planting rows. This study will increase technical and scientific knowledge and enrich the existing literature.

\section{MATERIAL AND METHODS}

The study was performed during the 2009/2010 harvest at the municipality of Chapadão do Sul, state of Mato Grosso do Sul (MS), Brazil (latitude 18\%40'27.81'S, longitude 5253'1.90”W, and altitude $852 \mathrm{~m}$ ). Direct sowing of the cotton cultivar FiberMax 993 was performed on 01/08/2010 following the bean harvest, with $0.76 \mathrm{~m}$ spacing between planting rows and a sowing density of 190,000 seeds $\mathrm{ha}^{-1}$. Plant emergence began on 01/14/2010.

Sowing was performed in a weed-free area. Base fertilization was applied at sowing with the application of $300 \mathrm{~kg} \mathrm{ha}^{-1}$ of single superphosphate. Top dressing fertilization was performed by broadcasting, with the application of $150 \mathrm{~kg} \mathrm{ha}^{-1}$ of ammonium sulfate 11 days after emergence (DAE), $100 \mathrm{~kg} \mathrm{ha}^{-1}$ of potassium chloride $26 \mathrm{DAE}$, and $60 \mathrm{~kg} \mathrm{ha}^{-1}$ of nitrogen 51 DAE. Prior to sowing, the dry matter on the ground equaled $0.75 \mathrm{tha}^{-1}$.

The soil in the experimental area was classified as a dystrophic Red Latosol (Oxisol) with a clay texture (EMBRAPA-CNPS, 2013). The 0-0.2 $\mathrm{m}$ soil layer presented the following chemical and physical characteristics: $59 \%$ clay, $28 \%$ sand, $13 \%$ silt, pH 6 in water, 3.4 cmolc $\mathrm{dm}^{-3} \mathrm{H}+\mathrm{Al}^{+3}$, 3.1 cmolc $\mathrm{dm}^{-3} \mathrm{Ca}^{+2}, 0.98$ cmolc $\mathrm{dm}^{-3} \mathrm{Mg}^{+2}$,

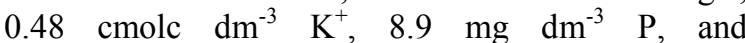
$33.6 \mathrm{~g} \mathrm{dm}^{-3} \mathrm{OM}$ (organic matter). The amount of rainfall during the experiment and the average rainfall in the region for the last ten years are presented in Table 1.

Table 1. Monthly (MR) and accumulated (AR) rainfall during the experiment and the average rainfall for the last 10 years (R10). Chapadão do Sul - MS, 2009/2010.

\begin{tabular}{ccccccccc}
\hline Rainfall & Jan/10 & Feb/10 & Mar/10 & Apr/10 & May/10 & Jun/10 & Jul/10 & Aug/10 \\
\hline MR & 322 & 444 & 150 & 17 & 32 & 0 & 5 & 0 \\
AR & 281 & 725 & 875 & 892 & 924 & 924 & 929 & 929 \\
R10 & 255 & 189 & 233 & 119 & 57 & 16 & 21 & 13 \\
\hline
\end{tabular}

Source: National Water Agency (Agência Nacional das Águas- ANA).

Growth regulators were used following the recommendations of Ferrari et al. (2008) (Table 2). A defoliant and a ripener were applied to achieve uniform fruit maturation. The products and doses applied are described in Table 2. 
Table 2. Treatments and times of application of growth regulators, defoliant, and ripener. Chapadão do Sul - MS, 2009/2010.

\begin{tabular}{|c|c|c|c|c|}
\hline Date & DAE & Aim & Product & $\begin{array}{c}\text { Dose } \\
\left(\mathrm{L} \mathrm{ha}^{-1}\right)\end{array}$ \\
\hline $03 / 15 / 10$ & 61 & Growth reg. & PIX HC (Mepiquat Chloride - $250 \mathrm{~g} \mathrm{~L}^{-1}$ ) & 0.12 \\
\hline$\overline{03 / 28 / 10}$ & 74 & $\overline{\text { Growth reg. }}-\overline{-}$ & PIX HC (Mepiquat Chloride $\left.-250 \mathrm{~g} \mathrm{~L}^{-1}\right)$ & $\overline{0.15}-\overline{1}$ \\
\hline$\overline{04 / 10 / 10}$ & $\overline{87}$ & Growth reg. & PIX HC (Mepiquat Chloride $\left.-250 \mathrm{~g} \mathrm{~L}^{-1}\right)$ & $0 . \overline{12}$ \\
\hline \multirow{2}{*}{$06 / 28 / 10$} & \multirow{2}{*}{166} & $\overline{\text { Defoliant }}$ & Dropp Ultra (Diuron+Thidiazuron $-60+120 \mathrm{~g} \mathrm{~L}$ ) & $\overline{0.2}$ \\
\hline & & Ripener & Finish (Cyclanilide+Ethephon - $\left.60+480 \mathrm{~g} \mathrm{~L}^{-1}\right)$ & 1.7 \\
\hline
\end{tabular}

Growth reg. $=$ Growth regulator.

A randomized block experimental design was used with 26 treatments and 8 replicates per treatment. The plots were composed of 7 rows that were $6 \mathrm{~m}$ in length $\left(31.92 \mathrm{~m}^{2}\right)$. The useful area consisted of the 5 central rows (excluding $0.5 \mathrm{~m}$ at both ends) for a total area of $19 \mathrm{~m}^{2}$.

Two treatment groups were set up. In the first group (G1), cotton plants were maintained in the presence of weeds for different periods of time following emergence to determine the period prior to weed interference (PPI). After each period of weed presence, the weeds were controlled manually until harvest. In the second group (G2), the cotton plants were maintained weed-free for increasing periods of time after emergence to estimate the total period of weed control (TPWC). After each tested weed-free period, the weeds were allowed to emerge freely. A total 13 different weed-free or weed presence periods (treatments) were evaluated $(0,5,10,15,22,29,36$, 43, 50, 57, 64, 71, and 190 days after cotton emergence) for a total of 26 treatments.

After each weed presence period for G1 and at the end of the crop cycle for G2, weed occurrence was evaluated in four $0.25-\mathrm{m}^{2}$ sampling areas selected randomly within the useful plot area. The plant density, dry weight, and frequency were determined for each weed species by calculating the relative importance (RI) of each weed species according to Mueller-Dombois and Ellenberg (1974). The RI was calculated as the ratio between the importance value index (IVI) for each species and the sum of the IVIs for all species and expressed as a percentage $(\mathrm{RI}=\mathrm{IVI} / \mathrm{IVIs})$.

Light transmittance in the crop canopy, which indirectly indicates canopy closure, was only determined for $\mathrm{G} 1$ at 100 DAE. Incident light $\left(\right.$ Lux $=$ Lumen $\left.\mathrm{m}^{-2}\right)$ was measured at four points in the inter-rows of the useful area of each plot using a lux meter (Minipa 1011). The measurements were performed between noon and 2:00 pm under a clear sky by placing the lux meter on the ground in the center of the inter-rows. Measurements were only performed for G1 because following an initial period of weed presence, G1 remained weed-free until the end of the crop cycle; therefore, the measurements were not affected by the presence of weeds.
At the end of the crop cycle and prior to harvest, the number of cotton plants in four linear meters from the two central rows of each plot and the number of bolls per plant in ten plants chosen randomly from the useful area of each plot were quantified.

When the point of harvest was reached (95\% of bolls), all bolls within the useful area of each plot were manually collected. The seed cotton weight $(\mathrm{g})$ for each plot was extrapolated to arroba $\mathrm{ha}^{-1}$ prior to analysis. Cotton moisture was determined using the oven-drying method and expressed on a dry basis. The periods of weed interference were determined using the seed cotton yield data through a polynomial regression analysis. The periods of weed interference were determined based on the regression equations fitted to the data considering the following levels of acceptable yield loss: a) 5\% yield reduction $=$ maximum $5 \%$ seed cotton yield reduction relative to the weed-free treatment (KNEZEVIC et al., 2002) and b) standard deviation $=$ yield reduction corresponding to the standard deviation for the weed-free treatment.

The data were tested for homogeneity of variance using Levene's test and normality using the Shapiro-Wilk test, and variance analysis was performed using the F-test $(\mathrm{p}<0.05)$. Regression analyses were performed within each experimental group.

The seed cotton yield (arrobas $\mathrm{ha}^{-1}$ ) data for G1 were best fitted by a Gompertz sigmoid function as follows: $\mathrm{Y}=\mathrm{B}+\mathrm{A} * \operatorname{EXP}\{-\mathrm{EXP}[-(\mathrm{DAE}-\mathrm{C}) / \mathrm{D})]\}$, where $\mathrm{Y}=$ the yield (arrobas $\mathrm{ha}^{-1}$ ), $\mathrm{A}=$ the maximum asymptote (arrobas $\mathrm{ha}^{-1}$ ), B = the minimum yield (arrobas $\mathrm{ha}^{-1}$ ) observed for the plots with a weed presence during the entire crop cycle, DAE = days after emergence during which the crop was in the presence of weeds, and $\mathrm{C}$ and $\mathrm{D}=$ constants. For the TPWC in G2, the data were best fitted by the following sigmoid function: $\mathrm{Y}=\quad \mathrm{A} /\{1+\exp [-(\mathrm{DAE}-\mathrm{B}) / \mathrm{C}]\}, \quad$ where $\mathrm{Y}=$ the yield (arrobas $\mathrm{ha}^{-1}$ ), $\mathrm{A}=$ the maximum asymptote (arrobas $\mathrm{ha}^{-1}$ ), $\mathrm{DAE}=$ days after emergence during which the crop remained weed-free, and $\mathrm{B}$ and $\mathrm{C}=$ constants. 


\section{RESULTS AND DISCUSSION}

The cotton crop cycle lasted 190 DAE, which was longer than expected for the tested late sowing and reduced spacing system and the reduced rainfall at the end of the crop cycle. Cultivar FM 993 presents a long crop cycle and vigorous plants, which may have contributed to the lengthening of the crop cycle (190 DAE). Indeed, the plant architecture and yield are highly dependent on the cultivar (KAGGWA-ASIIMWE, ANDRADE-SANCHEZ AND WANG, 2013).

The scientific name, common name, and families of the weed species found in the experimental area are presented in Table 3. Sixteen weed species belonging to nine different families were identified, most of which were dicotyledonous (81.25\% of all species found).

Table 3. Weed community found during the experimental period with the respective scientific names, common names and families. Chapadão do Sul - MS, 2009/2010.

\begin{tabular}{|c|c|c|}
\hline Species & Common name & Family \\
\hline \multicolumn{3}{|c|}{ Dicotyledoneae } \\
\hline Bidens pilosa & Hairy beggarticks & \multirow{3}{*}{ Asteraceae } \\
\hline Galinsoga parviflora & Gallant soldier & \\
\hline Tridax procumbens & Coatbuttons & \\
\hline Euphorbia heterophylla & Mexican fireplant & \multirow{2}{*}{ Euphorbiaceae } \\
\hline Chamaesyce hirta & Pillpod sandmat & \\
\hline Amaranthus retroflexus & Redroot amaranth & \multirow{2}{*}{ Amaranthaceae } \\
\hline Alternanthera tenella & Joyweed & \\
\hline Spermacoce latifolia & Oval-leaf false buttonweed & \multirow{2}{*}{ Rubiaceae } \\
\hline Richardia brasiliensis & Tropical Mexican clover & \\
\hline Commelina benghalensis & Jio & Commelinaceae \\
\hline Portulaca oleracea & Little hogweed & Portulacaceae \\
\hline Ipomoea grandifolia & Little bell & Convolvulaceae \\
\hline \multirow[t]{2}{*}{ Phaseolus vulgaris } & Common bean & Fabaceae \\
\hline & Monocotyledonae & \\
\hline Digitaria horizontalis & Jamaican crabgrass & \multirow{3}{*}{ Poaceae } \\
\hline Brachiaria plantaginea & Plantain signalgrass & \\
\hline Eleusine indica & Indian goosegrass & \\
\hline
\end{tabular}

In $\mathrm{G} 1$, the total weed density and the density of the main weed species increased until 15 DAE (Figure 1), when the highest total weed density was reached $\left(582\right.$ plants $\left.\mathrm{m}^{-2}\right)$. Then, the weed density decreased until 50 DAE and remained practically stable until the end of the experiment. Amaranthus retroflexus presented a high density during the initial period of competition with cotton, with 399 plants $\mathrm{m}^{-2}$ at 5 DAE (approximately $83 \%$ of the total weed density observed at that time) (Figure 1).

The high weed density observed during the initial periods of weed presence may have been due to higher soil moisture resulting from high rainfall and temperature, whereas the decrease may have related to weed mortality due to intra- and interspecific competition and shading by the crop.

For G2, the highest total weed density at the end of the crop cycle was observed for the treatment with weed control until 5 DAE (98 plants $\mathrm{m}^{-2}$; Figure 2). During this period, B. pilosa was the weed species with the highest density (44 plants $\mathrm{m}^{-2}$ ), corresponding to $44.90 \%$ of the total weed density. After this period, weed reinfestation decreased, resulting in densities lower than 10 plants $\mathrm{m}^{-2}$ at 57 DAE. The weed presence likely had little effect on the cotton yield at 57 DAE. Weeds that emerge later during the cotton crop cycle have lower effects on the cotton yield and represent a bigger problem during the cotton harvest (MAcRAE et al., 2013).

In $\mathrm{G} 1$, the highest dry weight accumulation $\left(1117 \mathrm{~g} \mathrm{~m}^{-2}\right)$ was observed for the treatment with a weed presence during the whole crop cycle (190 DAE) (Figure 3). B. pilosa presented a pronounced dry weight accumulation until 71 DAE $\left(473.10 \mathrm{~g} \mathrm{~m}^{-2}\right)$, when it represented $46.87 \%$ of the total weed dry weight.

For G2, the maximum weed dry weight accumulation was also observed for the treatment without weed control during the whole crop cycle $(0$ DAE). The weed dry weight accumulation resulting from weed reinfestation decreased with the increasing periods of weed control (Figure 4). 


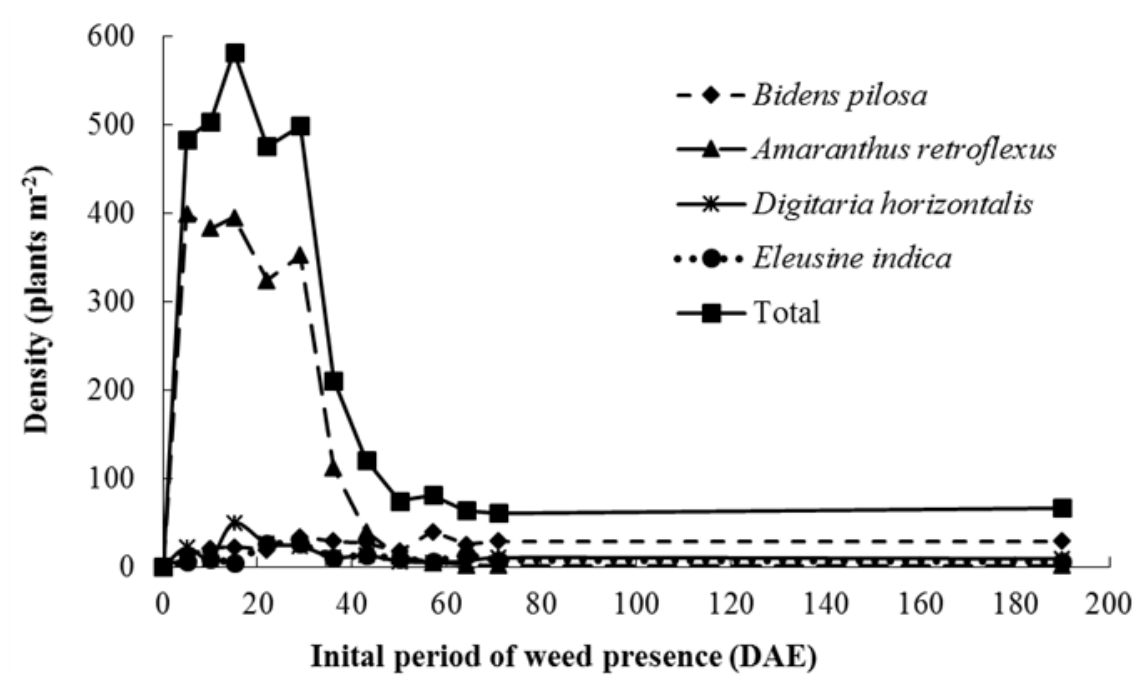

Figure 1. Total weed density and density of the main weed species for the treatments with the initial weed presence (G1). Chapadão do Sul - MS, 2009/2010.

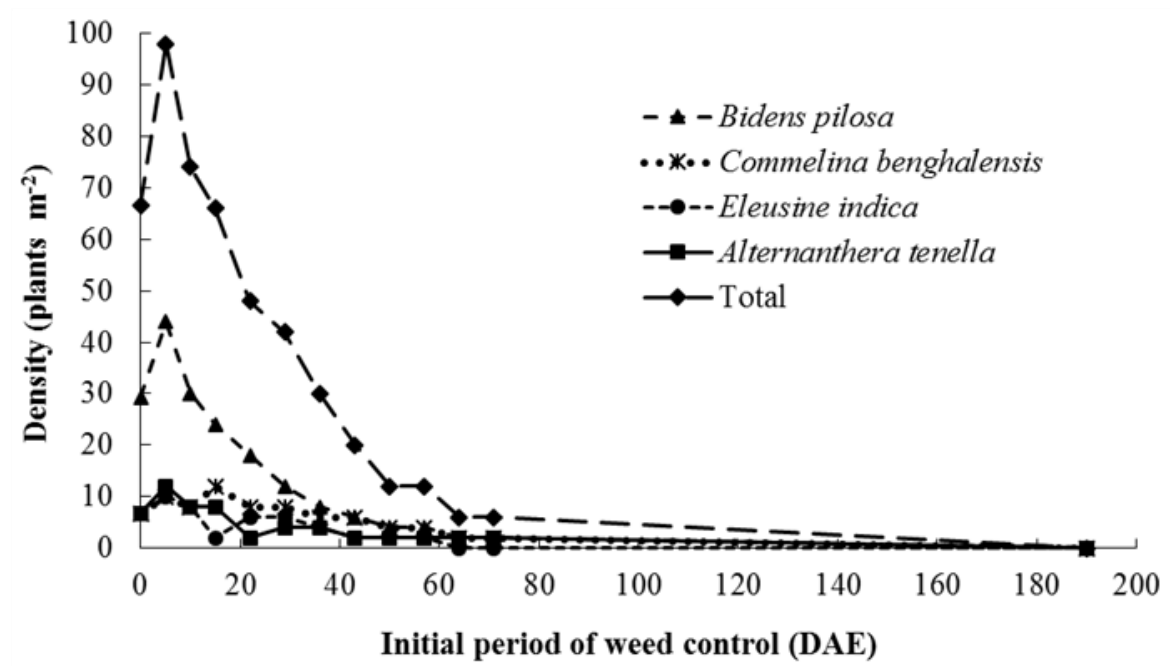

Figure 2. Total weed density and density of the main weed species for the treatments with initial weed control (Group 2). Chapadão do Sul - MS, 2009/2010.

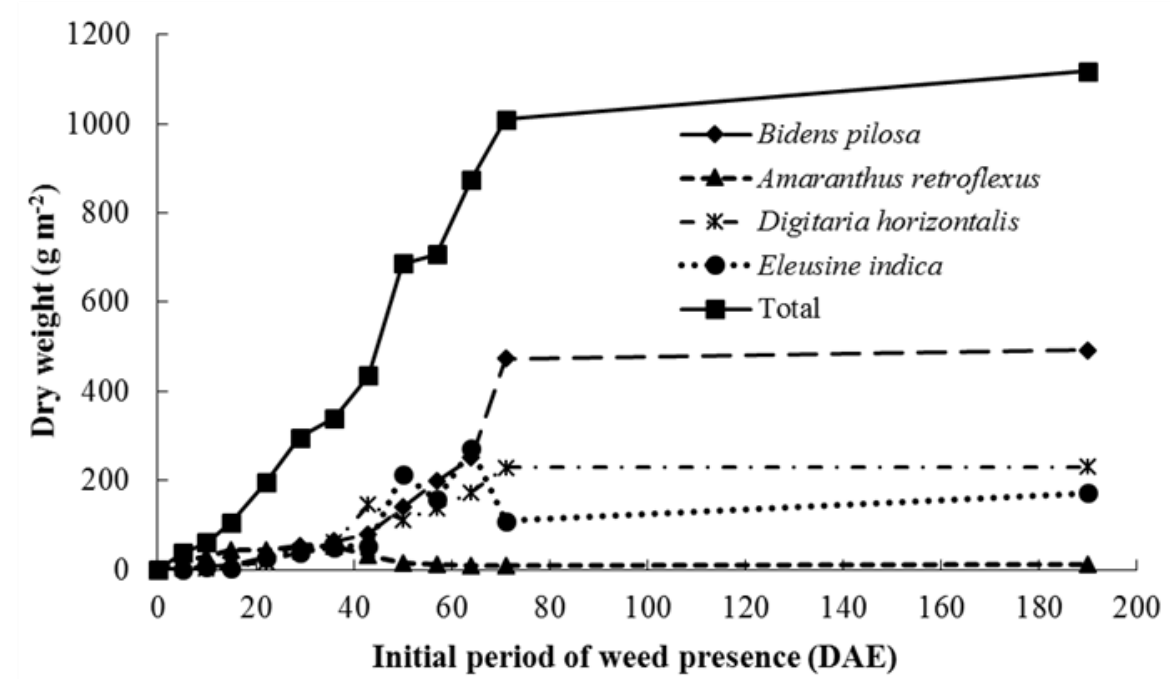

Figure 3. Total weed dry weight and dry weight of the main weed species for the treatments with initial weed presence (G1). Chapadão do Sul - MS, 2009/2010. 


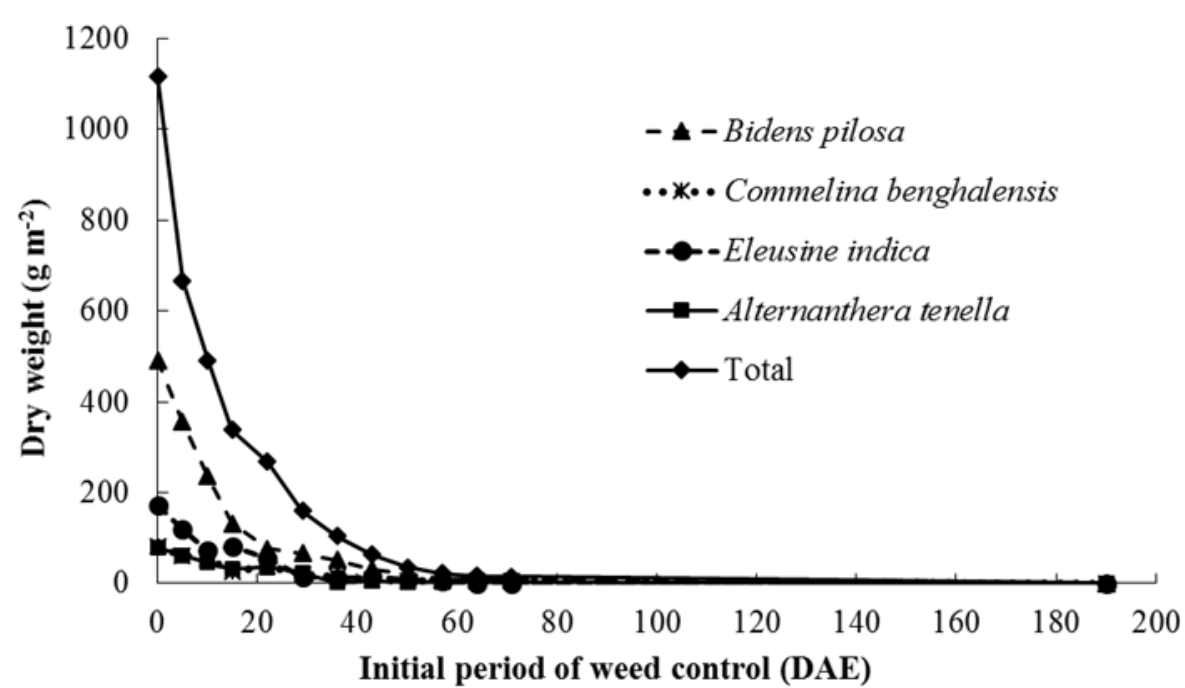

Figure 4. Total weed dry weight and dry weight for the main weed species for the treatments with initial weed control (Group 2). Chapadão do Sul - MS, 2009/2010.

The weed dry weight accumulation due to weed reinfestation for the treatment with weed control until 50 DAE (G2) was only $5.57 \%$ of the maximum accumulation observed. Shading due to the increasing cotton leaf area decreases light incidence at the inter-row, resulting in lower weed photosynthesis and development. Therefore, crop canopy closure is one of the main weed management tools, especially at the end of the crop cycle.
For G1, the highest RI was observed for $A$ retroflexus at 5 DAE (52.31\%) (Figure 5). However, the $A$. retroflexus RI gradually decreased at later evaluations. B. pilosa was the species with the highest RI at 50 DAE and reached its highest values at 71 DAE. The main monocotyledonous species were Eleusine indica and Digitaria horizontalis, which presented their highest RIs at 64 and 43 DAE, respectively.

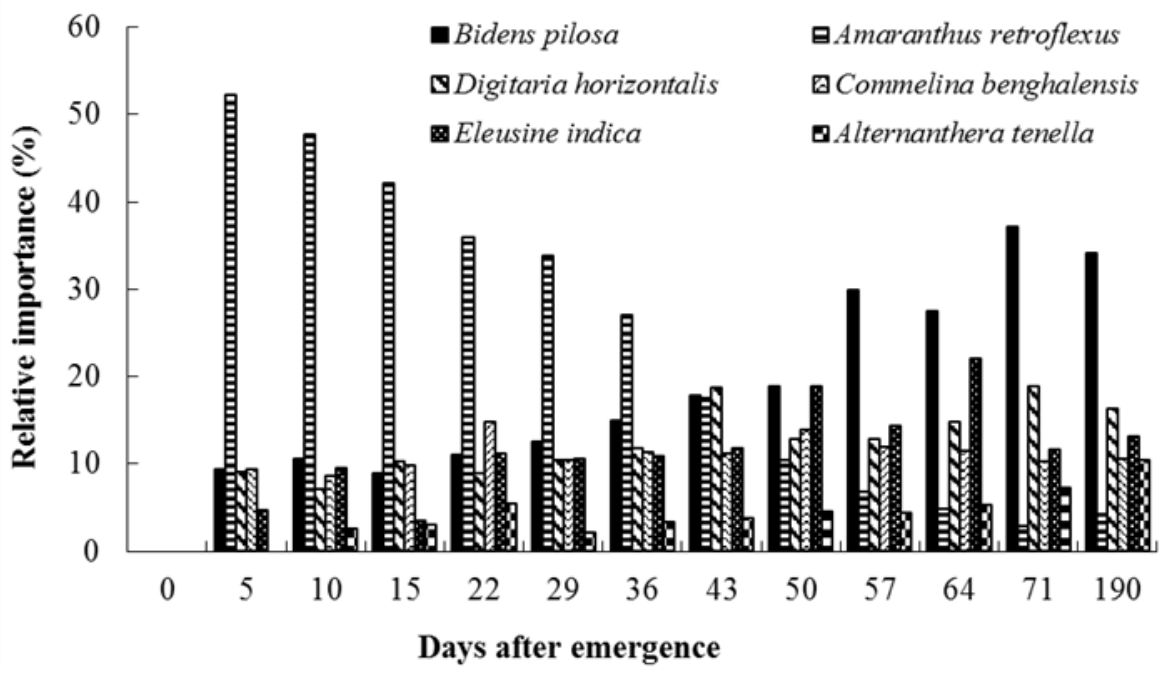

Figure 5. Relative importance (RI) of the main weed species present during the experiment for the treatments with different initial periods of weed presence (Group 1). Chapadão do Sul - MS, 2009/2010.

Species of the genus Amaranthus are highly frequent in the agricultural areas of the Cerrado (ISAAC; GUIMARÃES, 2008). These species strongly compete with cotton (CHANDI et al, 2013). Amaranthus retroflexus presented a high RI in the beginning of the crop cycle (Figure 5) and could have competed strongly with cotton during that period, thereby negatively affecting the crop yield.

In the $\mathrm{G} 2$ treatments, $B$. pilosa was the main weed species and presented the highest RI (41.39\%) observed for the treatment with weed control until 50 DAE (Figure 6). For the treatments with weed control on or after $64 \mathrm{DAE}$, the only weed species that emerged other than B. pilosa were Alternanthera tenella and Commelina benghalensis. The highest RI for A. tenella was $27.87 \%$, which was observed for the treatment with weed control until 64 DAE. The highest RI for $C$. benghalensis was $32.15 \%$, which was observed for the treatment with weed control until 71 DAE. 


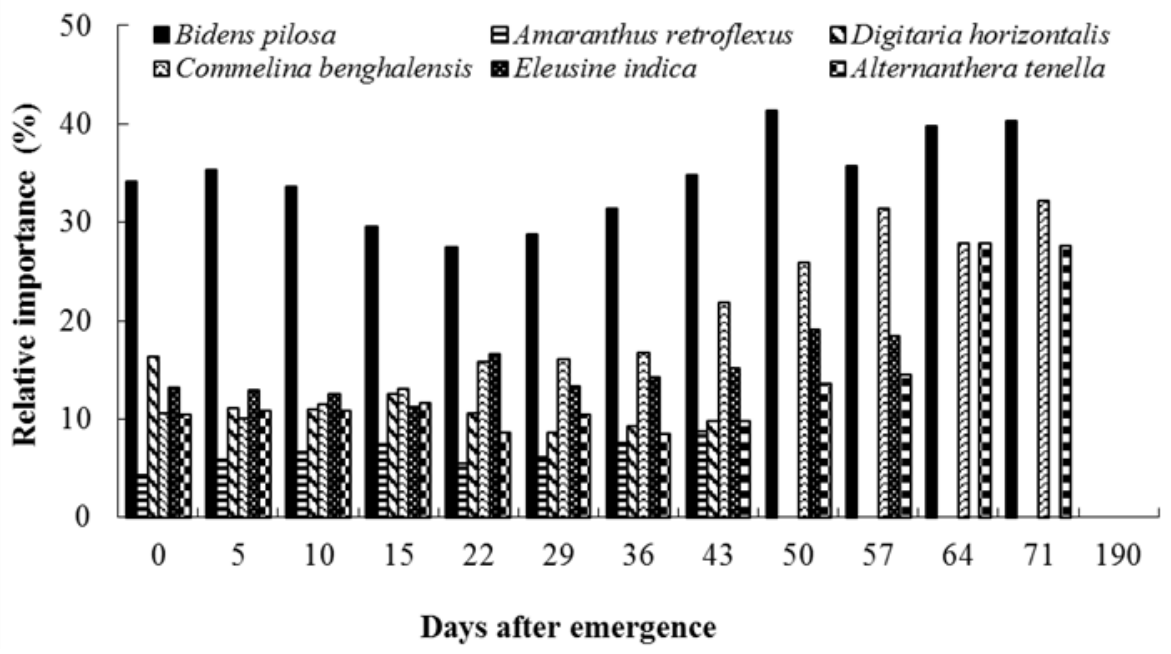

Figure 6. Relative importance (RI) of the main weed species present during the experiment for the treatments with different initial periods of weed control (Group 2). Chapadão do Sul - MS, 2009/2010.

Shorter initial periods of weed presence (up to approximately 25 DAE) had no effect on crop canopy closure (Figure 7). The characteristics of cultivar FM 993 (i.e., vigorous plant development) may result in stronger initial competition of cotton with weeds compared to other cotton cultivars. However, the reduced spacing tested here may result in higher and faster cotton canopy closure at the inter-row level, even with an initial weed presence (up to $25 \mathrm{DAE}$ ). Moreover, longer initial periods of weed presence negatively and more intensely affect crop canopy closure. The observed changes to the cotton canopy morphology resulting from weed competition are extremely detrimental to cotton physiology because each species needs to intercept a given quantity of light to complete its cycle and ensure yield stability (SUGANUMA et al., 2008). Therefore, these negative effects may result in a decreased plant yield.

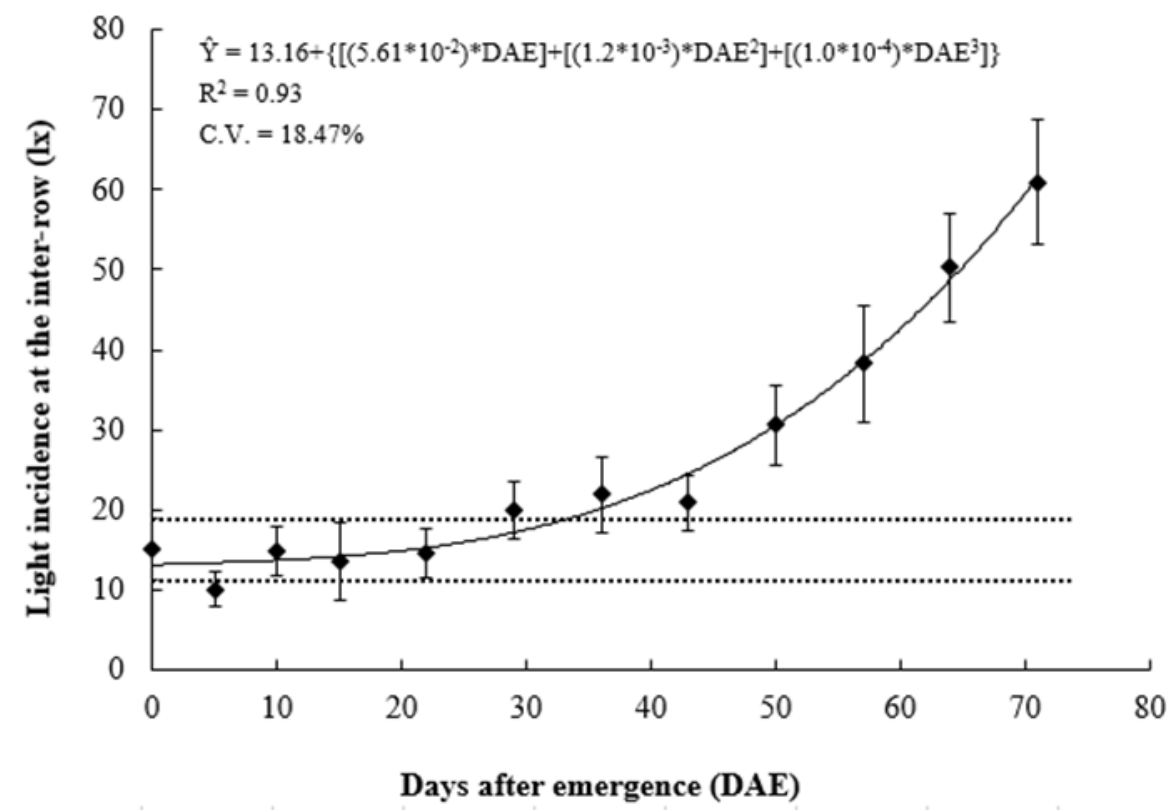

Figure 7. Light incidence at the inter-row (lx) 100 DAE for the treatments with initial weed presence. Values are the means \pm standard deviations. The dashed lines indicate the standard deviations for the weed-free treatment. Chapadão do Sul MS, 2009/2010.

All G1 treatments were negatively affected by this characteristic (cotton stand) compared to the weed-free treatment (Figure 8). The cotton stand decreased up to $65.68 \%$ when cotton was in the presence of weeds during the entire crop cycle.
For G2, weed control was necessary up to approximately 73 DAE because weed reinfestation following shorter periods of weed control caused a decrease in the final cotton stand (Figure 8). 


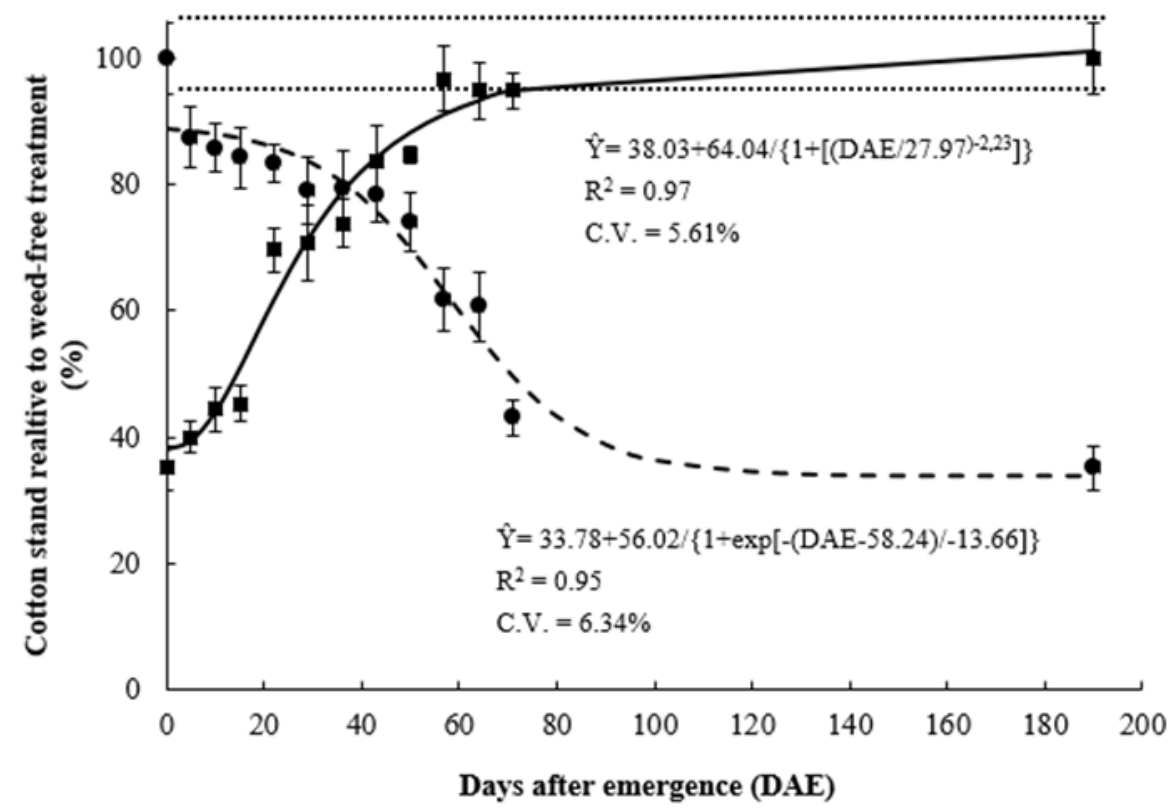

Figure 8. Final cotton stand relative to the weed-free treatment according to the initial period of weed presence $(\bullet)$ or weed control (ם). Values are the means \pm standard deviations. The dashed lines indicate the standard deviations for the weed-free treatment. Chapadão do Sul - MS, 2009/2010.

The effects of the weed presence on the number of bolls per plant was stronger for weed presence periods equal to or higher than $11 \mathrm{DAE}$ (G1) according to the standard deviations of the weed-free treatment (Figure 9). Weed competition during the entire crop cycle resulted in a $58 \%$ decrease in the number of bolls per plant.

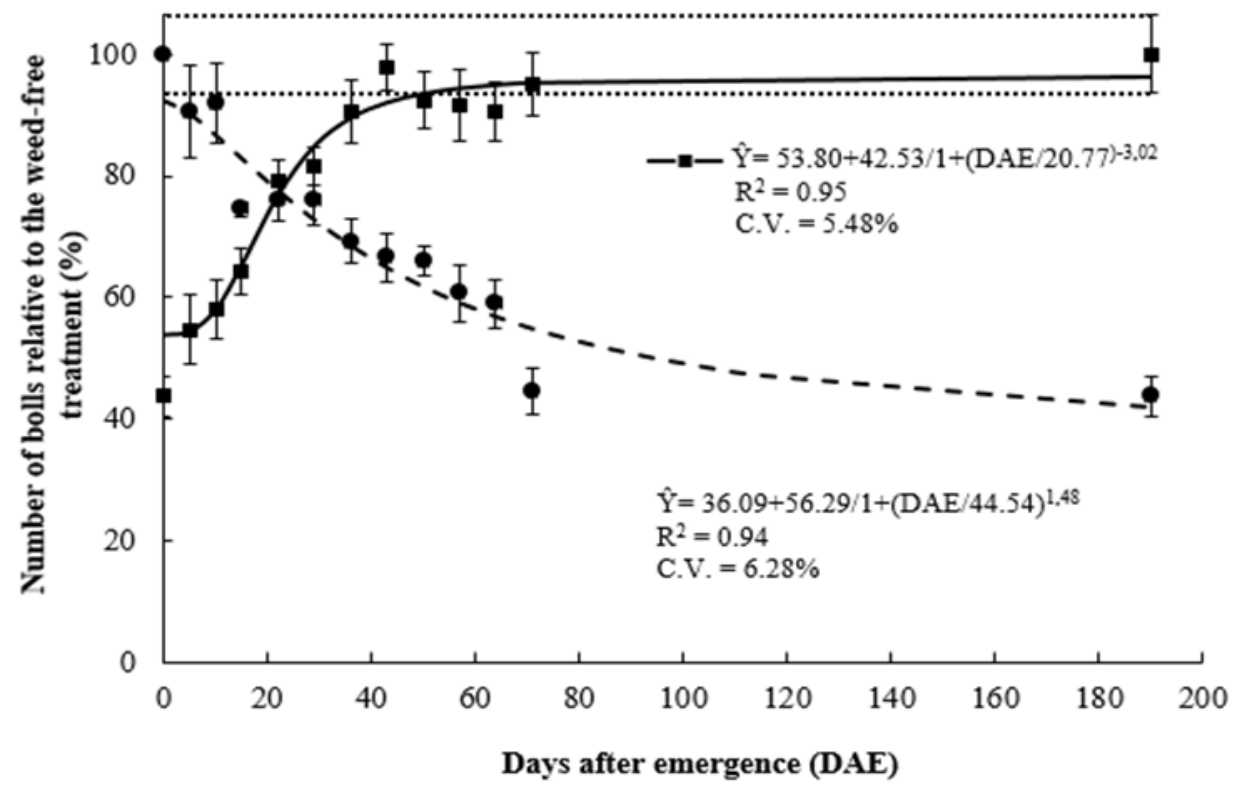

Figure 9. Number of bolls per plant relative to the weed-free treatment according to the initial period of weed presence $(\bullet)$ or weed control ( $\mathbf{a})$. Values are the mean \pm standard deviations. The dashed lines indicate the standard deviations for the weed-free treatment. Chapadão do Sul - MS, 2009/2010.

Negative effects on the number of bolls per plant were also more pronounced with a weed presence at the beginning of the crop cycle (Figure 9). Weed reinfestation (G2) following weed control for 37 DAE no longer affected this parameter. Although the conditions allowed weeds to germinate, emerge, and reestablish their population until approximately $37 \mathrm{DAE}$, the later that this process occurred, the more developed the cotton plants were likely to be and the higher their competitive power, resulting in lower weed interference.

The seed cotton yield curve as a function of the initial period of weed presence (G1) showed that 
the cotton yield was highest for the weed-free treatment (Figure 10) and lowest when the crop was subjected to weed interference during the whole crop cycle, with a decrease of $90.48 \%$ relative to the weed-free treatment. Considering a maximum acceptable yield loss of 5\%, the PPI was established at $11 \mathrm{DAE}$ of weed presence.

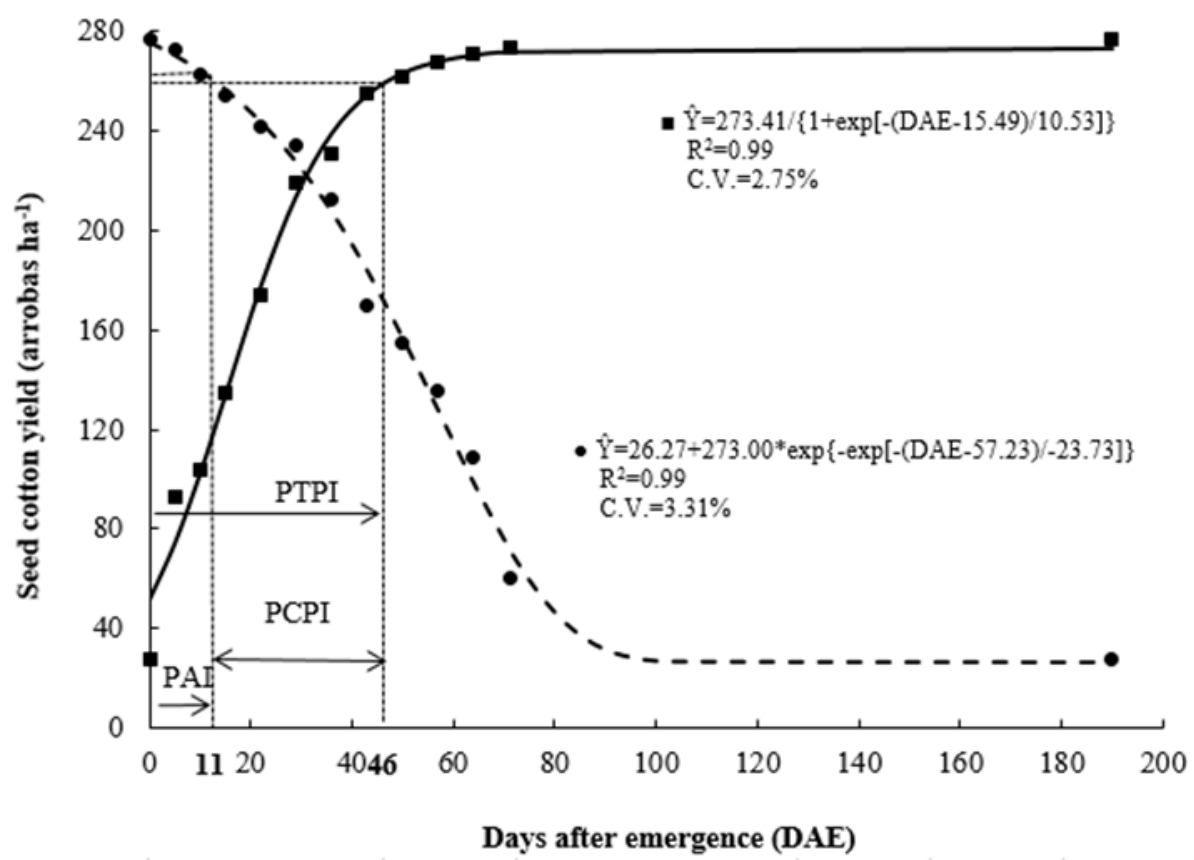

Figure 10. Seed cotton yield, PPI, TPWC, and CPWC according to the initial period of weed presence $(\bullet)$ or weed control (匹) considering an acceptable yield loss of 5\%. Chapadão do Sul - MS, 2009/2010.

The PPI for the studied system was expected to be longer than observed. The reduced spacing and increased plant density were expected to increase the competitive power of cotton but did not decrease early weed competition. The high weed density and dry weight during the initial periods of weed presence (especially for $A$. retroflexus, which presents high competitive power) may have been the main cause of the early negative effects on the cotton yield. Therefore, there was insufficient time for the tested sowing system to result in any benefits due to the early weed interference.

Competition between crops and weeds occurs when one or more resources essential to plant growth and development are present in limiting amounts in the environment (RIGOLI et al., 2008). However, significant yield decreases due to weed competition were observed during the first days after emergence when resources such as water or nutrients were certainly not yet limiting. Therefore, competition for light may have been one of the main causes of these negative effects. Before there is competition for the resources in the environment, the detection of a weed presence by the crop leads to a series of morphological changes, such as etiolation and an increase in leaf area, and physiological changes, such as changes in assimilate partitioning (VIDAL et al., 2008). The weed presence is detected by crops via changes in the light quality because the presence of neighboring plants causes a decrease in the ratio of red to far red light (GREEN-TRACEWICZ; PAGE;
SWANTON, 2011; LIU et al, 2009).

Cotton grown with weed control for $46 \mathrm{DAE}$ (TPWC) presented a cotton yield within the acceptable yield loss limit of $5 \%$ relative to the maximum yield (G2; Figure 10). Weed establishment after 46 DAE was no longer able to irreversibly affect the cotton growth and yield because the cotton plants were already capable of suppressing competitor plants (AGOSTINETTO et al., 2008). The critical period of weed control (CPWC) (i.e., the period of time during which cotton should be kept free from weed interference) for the tested sowing season and planting density began at $11 \mathrm{DAE}$ and ended at $46 \mathrm{DAE}$ for a total of 35 days.

The TPWC estimated in the present study was lower than that reported in previous studies of cotton grown with wider spacing (SALGADO et al., 2002). Reduced spacing or increased plant density increases the capacity of the crop to compete with weeds, especially for light, because it speeds crop canopy closure, thereby restricting light passage (SILVA et al., 2006; MAROIS et al., 2004). Weed control by cotton can be used to minimize weed growth and increase weed mortality, thereby decreasing yield losses (MORTENSEN et al., 2000). Azevêdo et al. (1994) reported that the light and $\mathrm{CO}_{2}$ availability for weeds and weed interference on cotton were higher with wider spacing.

In the present study, the higher competitive power of cotton over weeds can be explained by the decreased TPWC instead of the increased PPI. Even 
with lower spacing and higher plant density, the slow initial cotton growth indicates that its competitive power will be higher a few weeks after emergence. Thus, cotton will not benefit from the increased PPI but instead exhibit a decreased TPWC.

The weed interference periods considering a maximum acceptable yield loss equal to the standard deviation for the weed-free treatment (6.24 arrobas $\left.\mathrm{ha}^{-1}\right)$ are presented in Figure 11.
Considering this level of yield loss, a weed presence up to $6 \mathrm{DAE}$ did not affect the cotton yield. Longer periods of weed presence had significant negative effects on the cotton yield, indicating the need for weed control. Weed control for periods longer than 55 DAE are necessary to prevent the negative effects of weed presence on the cotton yield. Therefore, the CPWC was established between 6 and 55 DAE for a total of 49 days.

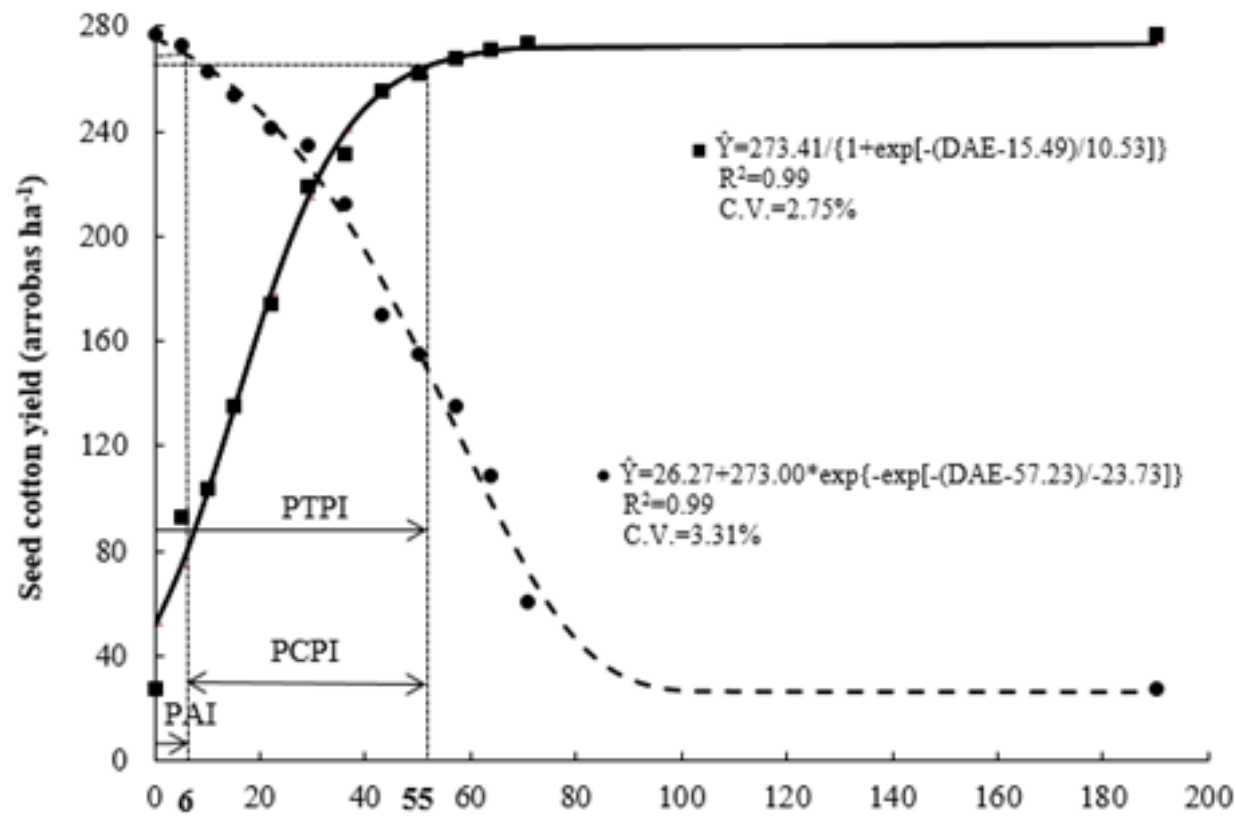

Days after emergence (DAE)

Figure 11. Seed cotton yield, PPI, TPWC, and CPWC according to increasing periods of weed presence $(\bullet)$ or weed control $(\boldsymbol{\Delta})$ considering an acceptable yield loss equal to the standard deviation for the weed-free treatment. Chapadão do Sul - MS, 2009/2010.

For G2, the weed density was highly negatively correlated with the cotton yield, number of bolls, and light transmittance (Table 4). This finding indicates that a higher weed reinfestation results in higher weed damage to the cotton yield and yield components. For G1, the weed density presented a low positive correlation with the analyzed parameters.

Table 4. Pearson product-moment correlation coefficient for the correlation between weed dry weight (DW) and density (D) and the cotton yield, stand, and number of bolls and light transmittance (LT).

\begin{tabular}{llllllll}
\hline \multirow{2}{*}{ Variables } & \multicolumn{2}{c}{ Yield } & \multicolumn{2}{c}{ Stand } & \multicolumn{2}{c}{ Number of bolls } & LT $^{1 /}$ \\
\cline { 2 - 7 } & Group 1 & Group 2 & Group 1 & Group 2 & Group 1 & Group 2 & Group 1 \\
\hline DW & $-0.9905^{*}$ & $-0.9614^{*}$ & $-0.9501^{*}$ & $-0.8844^{*}$ & $-0.9380^{*}$ & $-0.9447^{*}$ & $0.9539^{*}$ \\
D & $0.6643^{*}$ & $-0.9174^{*}$ & $0.4741^{\text {ns }}$ & $-0.9583^{*}$ & $0.4809^{\text {ns }}$ & $-0.9141^{*}$ & $-0.6374^{*}$ \\
\hline
\end{tabular}

${ }^{1 /}$ Only analyzed for group 1 treatments; *Significant at $\mathrm{p}<0.05$ according to the Pearson product-moment correlation

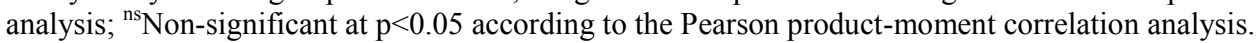

For G1, the cotton yield was more strongly and highly negatively correlated with the weed dry weight accumulation than with the weed density (Table 4). In the early cotton crop cycle, weed dry weight accumulation was more detrimental to the cotton yield than the increase in the weed density. Therefore, the weed dry weight may be used to determine the periods of competition between weeds and cotton.

\section{CONCLUSION}

Bidens pilosa and $A$. retroflexus were the main weed species observed in the present study, and 
A. retroflexus presented a higher RI during the early weed presence in the cotton crop. The weed dry weight was the parameter that correlated best with the seed cotton yield.

Considering an acceptable yield loss of 5\%, PPI was established at $11 \mathrm{DAE}, \mathrm{TPWC}$ at $46 \mathrm{DAE}$, and CPWC between 11 and 46 DAE for a total of 35 days. Considering the standard deviation of the weed-free treatment as an acceptable yield loss level, PPI was established at 6 DAE, TPWC at 55 DAE, and CPWC between 6 and 55 DAE for a total of 49 days.

The standard deviation of the weed-free treatment is the best parameter to use as an acceptable yield loss level for the determination of weed interference periods in cotton because it is a statistical parameter that is easy to calculate in research studies.

\section{REFERENCES}

AGOSTINETTO, D. et al. Período crítico de competição de plantas daninhas com a cultura do trigo. Planta Daninha, Viçosa, v. 26, n. 2, p. 271 278, 2008.

AZEVÊDO, D. M. P. et al. Período crítico de competição entre as plantas daninhas e o algodoeiro anual irrigado. Pesquisa Agropecuária Brasileira, Brasília, v. 29, n. 9, p. 1417-1425, 1994.

CHANDI, A. et al. Interference and control of glyphosate-resistant and -susceptible palmer amaranth (Amaranthus palmeri) populations under greenhouse conditions. Weed Science, Champaign, v. 61, n. 2 , p. $259-266,2013$

EMPRESA BRASILEIRA DE PESQUISA AGROPECUÁRIA - EMBRAPA. Centro Nacional de Pesquisa de Solos (CNPS). Sistema brasileiro de classificação de solos. 3. ed. Brasília, DF: EMBRAPA, 2013. 353 p.

FAIRCLOTH, J. C. et al. Na evaluation of alternative cotton harvesting methods in Northeast Louisiana - A compararison of the brush stripper and spindle harvester. The Journal of Cotton Science, Baton Rouge, v. 8, n. 1, p. 55-61, 2004.

FERRARI, S. et al. Desenvolvimento e produtividade do algodoeiro em função de espaçamentos e aplicação de regulador de crescimento. Acta Scientiarum Agronomy, Maringá, v. 30, n. 3, p. 365-371, 2008.

GREEN-TRACEWICZ, E.; PAGE, E. R.; SWANTON, C. J. Shade avoidance in soybean reduces branching and increases plant-to-plant variability in biomass and yield per plant. Weed
Science, Champaign, v. 59, n. 1, p. 43-49, 2011.

ISAAC, R. A.; GUIMARÃES, S. C. Banco de sementes e flora emergente de plantas daninhas. Planta Daninha, Viçosa, v. 26, n. 3, p. 521-530, 2008.

KAGGWA-ASIIMWE, R.; ANDRADE-SANCHEZ, P.; WANG, G. Plant architecture influences growth and yield response of upland cotton population density. Field Crops Research, Amsterdam, v. 145, n. 145 , p. 52-59, 2013.

KNEZEVIC, S. Z. et al. Critical period for weed control: the concept and data analysis. Weed Science, Champaign, v. 50, n. 6, p. 773-786, 2002.

LIU, J. G. et al. The importance of light quality in crop-weed competition. Weed Research, Oxford, v. 49 , n. 2 , p. $217-224,2009$

MacRAE, A. W. et al. Cotton yield loss potential in response to length of palmer amaranth (Amaranthus palmeri) interference. The Journal of Cotton Science, Baton Rouge, v.17, n.1, p.227-232, 2013.

MAROIS, J. J. et al. Effect of row width and nitrogen on cotton morphology and canopy microclimate. Crop Science, Madison, v. 44,n. 3, p. 870-877, 2004.

MORTENSEN, D. A.; BASTIAANS, L.; SATTIN, $M$. The role of ecology in the development of weed management systems: an outlook. Weed Research, Oxford, v. 40, n. 1, p. 49-62, 2000.

MUELLER-DOMBOIS, P.; ELLENBERG, H. Aims and methods of vegetation ecology. New York: John Willey and Sons, 1974. 547 p.

RIGOLI, R. P. et al. Habilidade competitiva relativa do trigo (Triticum aestivum) em convivência com azevém (Lolium multiflorum) ou nabo (Raphanus raphanistrum). Planta Daninha, Viçosa, v. 26, n. 1, p. 93-100, 2008.

SALGADO, T.P. et al. Períodos de interferência das plantas daninhas na cultura do algodoeiro (Gossypium hirsutum). Planta Daninha, Viçosa, v. 20 , n. 3 , p. $373-379,2002$

SILVA, A. V. et al. Crescimento e desenvolvimento do algodoeiro em diferentes configurações de semeadura. Bragantia, Campinas, v. 65, n. 3, p. $407-$ $411,2006$.

STEPHENSON, D. O. et al. Effect of twin-row planting pattern and plant density on cotton growth, yield, and fiber quality. The Journal of Cotton Science, Baton Rouge, v. 15, n. 3, p. 243-250, 2011. 
SUGANUMA, M. S. et al. Comparando metodologias para avaliar a cobertura do dossel e a luminosidade no sub-bosque de um reflorestamento e uma floresta madura. Revista Árvore, Viçosa, v. 32, n. 2, p. 377-385, 2008.

VIDAL, R. A. et al. Initialism: a new term to describe the first mechanism of negative interaction between weeds and crops. Journal of Plant

Diseases and Protection, Braunschweig, v. 21, n. 1, p. 595-98. 2008. 